\title{
Variations of Human Milk Compositions as per Prakriti (Psychosomatic Constitution): A Pilot Study
}

\author{
Deeksha Singh ${ }^{1 *}$, Sangeeta Gehlot ${ }^{2}$, B. M. Singh ${ }^{3}$, and D. C. Rai ${ }^{4}$ \\ ${ }^{1}$ Home Science, Allied Discipline, Department of Kriya Sharir, Faculty of Ayurveda, Institute of Medical \\ Sciences, Banaras Hindu University, Varanasi - 221005, Uttar Pradesh, India; deeksha.ksy@gmail.com \\ ${ }^{2}$ Department of Kriya Sharir, Faculty of Ayurveda, Institute of Medical Sciences, \\ Banaras Hindu University, Varanasi - 221005, Uttar Pradesh, India; sangeetagehlot@gmail.com \\ ${ }^{3}$ Department of Kaumarbhritya and Balaroga, Faculty of Ayurveda, Institute of Medical Sciences, Banaras \\ Hindu University, Varanasi - 221005, Uttar Pradesh, India; hodkb2006@yahoo.in \\ ${ }^{4}$ Department of Animal Husbandry and Dairying, Institute of Agricultural Sciences, Banaras Hindu University, \\ Varanasi - 221005, Uttar Pradesh, India; dcrai.bhu@gmail.com
}

\begin{abstract}
Introduction: Mother's milk is considered to be the supreme food for neonates, infants and toddler. It is also regarded as the finest gift form a mother to her baby. The individual characteristic of a person enumerating external and internal body features is known as Prakriti. It is the sense of personality or constitution or temperament of an individual. The aim of the present study was to assess "variations of human milk composition as per Prakriti". Materials and Methods: Total 64 lactating mothers of 20-35 years age group, not suffering from any acute or chronic illness and who were on similar diet regardless of their mode of delivery were registered and included in the study while lactating mothers not falling in this age group or who were taking any specific drug for the illness or suffering from any disease including- moderate $(9.97-7 \mathrm{~g} / \mathrm{dl})$ to severe $(6.94-4 \mathrm{~g} / \mathrm{dl})$ anemia were excluded from the study. Result: On applying One Way ANOVA, the mean values of fat percentage in milk varied significantly as per Prakriti $(\mathrm{p}=0.0287)$. On applying Post Hoc Test the significant pairs were for Vata vs. Pitta $(<\mathbf{0 . 0 5})$ and Vata vs Kapha $(<\mathbf{0 . 0 5})$ Prakriti. In all other parameters of milk, no significant variation was found. Conclusion: We can conclude that the composition of mother's milk varies as per Prakriti.
\end{abstract}

Keywords: Ayurveda, Body Constitution, Fat, Lactose, Milk Composition

\section{Introduction}

Human milk has been regarded as the best and complete nourishment for infants. It offers the best physiological nourishment to the infants and its composition is used to estimate the nutritional requirements of neonates and to guide the milk composition of mothers ${ }^{1}$. All mammalian milks have highly specific biochemical compositions which reflect a specific physiologic needs to ensure optimal growth, development, and survival of the offspring ${ }^{2}$. Although human milk is not a uniform body fluid but a secretion of the mammary gland of changing in composition. Fore milk differs from hind milk, colostrum differs from transitional milk and mature milk. Milk changes over time of the day, time based concentrations of protein, fat, carbohydrates, minerals and also with cells as they differ in physical properties such as osmolarity and $\mathrm{pH}^{3}$. Composition

${ }^{*}$ Author for correspondence 
of breast milk is also affected by maternal, genetic and environmental factors like, life style, dietary habits and psychological factors etc. ${ }^{4,5}$. The composition of breast milk can also differ as per the maternal Prakriti due to difference in nutritional status and metabolizing ability in accordance to Prakriti. Prakriti is sum total of physical, physiological and psychological characteristics of any individual and represents the genotype ${ }^{6}$. This study was carried out with the aim to find out the variations in composition of breast milk among lactating mothers of different Prakriti. Outcome of this study can be used for the dietary and life style modifications of lactating mothers for optimizing the differences in composition of milk. As breast milk is the sole source of nutrition in first six month of life and hence forth might have effect on growth and development of infants. Thus their effect can be observed on infants and correcting the lagging of growth and development in its initial phase itself.

\section{Material and Methods}

\subsection{Study Design and Participants}

The study proposal was approved from ethical committee of the institute vide letter number is dean/2014-15/ EC/1322 dated 02/09/2015. For this study lactating mothers were registered after $15 \pm 5$ days of delivery, after getting informed written consent. Participants were selected from OPD/IPD of Department of Kaumaryabhritya/Balaroga, Sir Sunderlal Hospital, Institute of Medical Sciences, Banaras Hindu University.

Lactating mothers of age group 20-35 years, not suffering from any acute or chronic illness and who were on similar diet regardless of their mode of delivery were included in the study while lactating mothers not falling in this age group or who were taking any specific drug for the illness or suffering from any disease includingmoderate $(9.97-7 \mathrm{~g} / \mathrm{dl})$ to severe $(6.94-4 \mathrm{~g} / \mathrm{dl})$ anemia were excluded from the study. On the basis of these criteria 64 lactating mothers were included in the study.

\subsection{Assessment of Maternal Prakriti (Psychosomatic Constitution)}

It was assessed through a reliable and validated performa designed by Tripathi PK et al, 2016 ${ }^{7}$. This Performa was based on the characteristics of Vata, Pitta and Kapha
Prakriti individuals as described in various Ayurvedic Samhitas. Ek Doshaja Prakriti was assigned on the basis of highest percentage of Dosha (more than 40\%) and difference of at least 7\% between two Dosha.

\subsection{Method of Collection of Milk Samples}

After informed consent, under all the recommended precautions, the mothers were asked to wash their hands and breast particularly nipple and areola part with soap water properly and were allowed to dry. Physical examination was done for the absence of cracked nipple, breast abscess etc. They were asked to express their one breast completely (at least $50 \mathrm{ml}$ ) in a sterile container with the help of breast milk pump ${ }^{8}$. After complete emptying of one breast, milk was transferred to another container for further evaluation.

\subsection{Method for Breast Milk Analysis}

Analysis of milk was done through Eco milk Analyzer (EON Trading LLC, USA Company) in Department of Animal Husbandry and Dairy, Institute of Agriculture Sciences, BHU. The working principle of analyzer is based upon the ultra sound technology and does not require any reagent or chemicals for the test. First of all, the sucker point of the analyzer was washed with the distilled water by allowing the water to be drawn through it. The milk was taken in three different test tubes in equal quantity; one tube was placed in $\mathrm{pH}$ electrode while one in temperature slot for their finding and milk of one tube was allowed to be sucked for the assessment of the following parameters:

- Fat $(\%) \pm 0.1 \%$

- Solid Non Fat (\%) $\pm 0.2 \%$

- Milk Density $(\mathrm{g} / \mathrm{cm} 3) \pm 0.0005 \mathrm{~g} / \mathrm{cm} 3$

- Protein $(\%) \pm 0.2 \%$

- Lactose $(\%) \pm 0.2 \%$

- Freezing point $\left({ }^{\circ} \mathrm{C}\right) \pm 0.015^{\circ} \mathrm{C}$

- Conductivity $(\mathrm{mS} / \mathrm{cm}) \pm 1 \%\left(18^{\circ} \mathrm{C}\right)$

- $\mathrm{pH} \pm 0.02$

\section{Observations and Result}

Table 1 depicts the composition of milk as per maternal Prakriti. The mean values of fat percentage 
in Vata, Pitta and Kapha Prakriti mother's milk sample were $3.1 \pm 0.6041,3.8 \pm 1.231$ and $3.7 \pm 0.8572$ respectively. The mean values of SNF, density and lactose was found maximum i.e., $9.45 \pm 0.5924,32.72 \pm 6.3554$ and $5.13 \pm 0.686$ respectively in Kapha Prakriti mother's milk. The mean values of protein were maximum (1.63 \pm 0.668) in Pitta Prakriti mother's milk while freezing point was minimum $(49.57 \pm 13.817)$ among the milk of these mothers. The mean values of conductivity and $\mathrm{pH}$ were maximum among Vata Prakriti mother's milk. On applying One Way ANOVA the mean values of fat percentage in milk varied significantly as per Prakriti $(\mathrm{p}=0.0287)$. On applying Post Hoc Test the significant pairs were for Vata vs. Pitta $(<\mathbf{0 . 0 5})$ and Vata vs. Kapha $(<\mathbf{0 . 0 5})$ Prakriti. In all other parameters of milk, no significant variation was found.

\section{Discussion}

Many studies regarding the variation in composition of mother milk have been done but till date no research work has been done to assess the milk composition as per the Prakriti of mother. 64 samples of milk were analyzed, by EKO milk analyzer, for the assessment of the composition of milk among different Prakriti mothers. On statistical analysis, the difference in mean values of fat percentage was found to vary significantly among the Vata vs. Pitta $(p<0.05)$ and Vata vs. Kapha $(p<0.05)$, while other parameters do not $(\mathrm{p}>0.05)$ vary significantly. However, difference in mean values of all the constituents were observed but being statistically insignificant, the mean values of these parameters like SNF\%, density, lactose\%, Freezing point were found maximum in milk of Kapha Prakriti mothers while density, lactose $\%, \mathrm{pH}$, freezing point of milk samples of Pitta Prakriti mothers were observed minimum.

These variations in Prakriti wise milk constituents may be due to change in feeding time and pattern, gender of infant, mother's diet, sleep, environmental factors.

Phenotypic descriptions are the expression of genotypes and current study by Govindraj P et al., 2015, ${ }^{9}$ proved that the phenotypic classification of India's traditional medicine has a genetic basis; and its Prakriti based practice in vogue for various centuries. Variation

Table 1. Composition of milk as per Prakriti of lactating mothers

\begin{tabular}{|c|c|c|c|c|c|}
\hline $\begin{array}{l}\text { Composition of } \\
\text { milk }\end{array}$ & $\begin{array}{c}\text { Vata Prakriti } \\
(\text { Mean } \pm \text { SD) } \\
(n=22)\end{array}$ & $\begin{array}{c}\text { Pitta Prakriti } \\
\text { (Mean } \pm \text { SD) } \\
(n=15)\end{array}$ & $\begin{array}{c}\text { Kapha Prakriti } \\
(\text { Mean } \pm \text { SD) } \\
(n=27)\end{array}$ & One Way ANOVA & Post Hoc Test \\
\hline Fat(\%) & $3.1 \pm 0.6041$ & $3.8 \pm 1.231$ & $3.7 \pm 0.857$ & $\begin{array}{l}F=3.7676 \\
\mathbf{p}=\mathbf{0 . 0 2 8 7}\end{array}$ & $\begin{array}{c}\text { Vata vs. Pitta } \mathbf{p}<\mathbf{0 . 0 5} \\
\text { Vata vs. Kapha } \mathbf{p}<\mathbf{0 . 0 5} \\
\text { Pitta vs. Kapha } \mathbf{p}=\mathbf{0 . 9 3 4 8}\end{array}$ \\
\hline SNF (\%) & $8.90 \pm 1.050$ & $8.95 \pm 1.158$ & $9.45 \pm 0.592$ & $\begin{array}{l}F=2.6282 \\
p=0.0804\end{array}$ & \\
\hline $\begin{array}{l}\text { Density } \\
(\mathrm{g} / \mathrm{cm} 3)\end{array}$ & $31.95 \pm 4.411$ & $31.26 \pm 4.596$ & $32.72 \pm 6.355$ & $\begin{array}{l}F=0.3728 \\
p=0.6904\end{array}$ & \\
\hline Protein (\%) & $1.5 \pm 0.284$ & $1.63 \pm 0.668$ & $1.5 \pm 0.433$ & $\begin{array}{l}F=0.2733 \\
p=0.7618\end{array}$ & \\
\hline Freezing Pointt $\left({ }^{\circ} \mathrm{C}\right)$ & $53.19 \pm 6.006$ & $49.57 \pm 13.817$ & $54.29 \pm 10.149$ & $\begin{array}{l}F=1.0974 \\
p=0.3402\end{array}$ & \\
\hline Lactose (\%) & $5.02 \pm 0.660$ & $4.89 \pm 0.590$ & $5.13 \pm 0.686$ & $\begin{array}{l}F=0.6540 \\
p=0.5236\end{array}$ & \\
\hline $\begin{array}{l}\text { Conductivity } \\
(\mathrm{mS} / \mathrm{cm})\end{array}$ & $1.86 \pm 0.387$ & $1.85 \pm 0.335$ & $1.75 \pm 0.343$ & $\begin{array}{l}F=0.6896 \\
p=0.5057\end{array}$ & \\
\hline $\mathrm{pH}$ & $6.40 \pm 0.378$ & $6.26 \pm 0.376$ & $6.28 \pm 0.536$ & $\begin{array}{l}F=0.5819 \\
p=0.5619\end{array}$ & \\
\hline
\end{tabular}


in fat concentration in pure milk of different Prakriti may be considered as a result of maternal genotypes in addition to maternal diet, sleep, and environment ${ }^{10}$.

\section{Conclusion}

Based on this study, we can conclude that the composition of breast milk varies in accordance to Prakriti of mothers as fat \% is maximum among Pitta Prakriti mothers then in Kapha Prakriti mother's milk as standard deviation is more and sample size is less in Pitta Prakriti mother's milk, if this study will be done with large sample size then this value of fat $\%$ may be maximum among the milk of Kapha Prakriti mothers. Fat \% of mother milk has a clear cut association with the Prakriti of mother.

\section{Acknowledgement}

None

\section{Conflict of Research}

None

\section{References}

1. Brunella C, Concetta B, Francesco S, Maria AA, Elisabetta S. Nitrogenous components of human milk: Non protein nitrogen, true protein and free amino acids food chemistry. FAOUN. 2003; 81:357-62. https://doi.org/10.1016/S0308-8146(02)00430-2
2. Picciano MF. Nutrient composition of human milk. Pediatr Clin North Am. 2001; 48(1): 53-67. https://doi.org/10.1016/S0031-3955(05)70285-6

3. Narang APS, Bains HS, KansalS, Singh D. Serial composition of humanmilkinpretermandtermmothers.IndianJClinBiochem. 2003; 21(1): 89-94. https://doi.org/10.1007/BF02913072. PMid:23105575. PMCid:PMC3453757

4. Singh BM. Editor. 1st Ed. Textbook of Balaroga Kaumarbhritya, Chaukhambha Orientalia Varanasi; 2015.

5. Tiwari PV. Editor. 1st Ed. Ayurveda Prasuti-Tantra Avam Stree Roga. Varanasi: Chaukhambha Vishvabharti; 2009.

6. Kunte AM, Navare KS. Reprint edition. Ashtanga Hridaya of Vagbhatta with Sarvangasundara commentary of Arundutta. Sutrasthana; Chapter 1: Ayushkamiyadhyaya, Verse 9. Varanasi : Chaukhambha Sanskrita Sansthana; 2016.

7. Tripathi PK, Gehlot S. A physio-anatomical study of prakriti [Internet]. [cited 2017 Nov 8]. Available from: http://www. lulu.com/ca/fr/shop/piyush-kumar-tripathi-and-sangeetagehlot/a-physio-anatomical-study-of-prakriti/paperback/ product-23213334.html.

8. Lovelady CA, Dewey KG, Picciano MF, Dermer A. Guidelines for collection of human milk Samples for monitoring and research of environmental chemicals. Journal of Toxicology and Environmental Health, Part A. 2002; 65:1881-91. https:// doi.org/10.1080/00984100290071775. PMid:12470492

9. Govindaraj P, Nizamuddin S, Sharath A, Vuskamalla J, Rotti $\mathrm{H}$ et al. Genome-wide analysis correlates Ayurveda Prakriti. Sci. Rep. 2015; 5:157-86. https://doi.org/10.1038/srep15786. PMid:26511157. PMCid:PMC4625161

10. Lee H, Padhi E, Hasegawa Y, Larke J, Parenti M, Wang A, Hernell O, Lönnerdal B, Slupsky C. Compositional dynamics of the milk fat globule and its role in infant development. Frontiers in Pediatrics. 2018; 6:1-2. https://doi.org/10.3389/ fped.2018.00313. PMid:30460213. PMCid:PMC6232911 